551.4

\author{
- Л Пчук \\ ьвівський н ціон льний університет імені в н \\ вул. . орошенк , 41, м. ьвів, 79000, кр їн
}

ведено дет льну х р ктеристику екзогенних морфодин мічних процесів у елятинській улоговині (к рстові, схилові, селеві, болотні процеси т процеси вивітрюв ння), т кож інформ цію про к т строфічні п водки н р. рут упродовж 1868-2007 pp. т дин міку зсувних процесів протягом 1955-2007 pp.

лючові слов : морфодин мічні процеси, п водки, зсуви, обв ли, селі.

ідпочинок у рп т х н був ост ннім ч сом зн чного розвитку, що є позитивним моментом для регіону. ьому сприяють усі природні чинники. роте є й інший бік нег тивний вплив людини н природу, що вир ж ється як у безпосередньому впливові н природні екосистеми (у тім числі й н рельєф), т к і в опосередков ному - ктивіз ції екзогенних морфодин мічних процесів. рикл д ми нег тивного впливу $\epsilon$ м сов з будов гірських територій, як передб ч є вирубув ння лісів, ч сткову зміну рельєфу, зміну гідрологічного режиму, що н д лі може спричинити т кі нег тивні морфодин мічні процеси як ерозія, п водки, селі, зсуви, обв ли тощо. ля з побіг ння цим процес м т збереження н вколишнього середовищ у н йменш зміненому вигляді необхідно дет льно досліджув ти процеси, які в гірській місцевості є особливо ктивними.

омплексні дослідження дин міки морфодин мічних процесів є одними з пріоритетних т необхідних н прямів н укових досліджень у гірських умов х, н с мперед у гірській ч стині $б$ сейну р. рут. е зумовлено різкою ктивіз цією морфодин мічних процесів, спричинених нтропогенною діяльністю в минулі періоди розвитку суспільств . кл д ння цих скл дових у нед лекому м йбутньому може призвести до к т строфічних н слідків. иявлення, обстеження, вивчення т попередження цих процесів сприятиме ст лому розвитку природних комплексів кр їнських рп т.

кзогенні процеси в кр їньких рп т х т ередк рп тті досліджув ло б г то вчених, серед яких . йзенберг, . ундін т . еменіхін [1], . иблюк, . ов льчук т . тир нівський [2], . іл нюк т . омин [3], . олюх, . н ш, . іт т . р вчук [4], . ожик [5, 6], . л пчук зі спів вт. [7-9], . р вчук [10-13], врук, . ельник т . ов льчук [14], . ельник $[15,16]$, . ліферов [17], . удько $[18,19]$, . ливк зі спів вт. [20, 21], . т дницький, . р вчук т ін. [22, 23], · усідко, . ук'янець [24], . омин [25], • ушняк т • в ник [26-28], . блонський [29] т ін.

и впродовж 2004-2008 pр. досліджув ли морфодин мічні процеси у елятинській улоговині з з г льноприйнятою в геоморфології методикою проведення польових досліджень.

(C) л пчук ., 2010 
роцеси вивітрюв ння поширені м йже н всій суходільній поверхні н шої пл нети. ивітрюв ння - це сукупність процесів руйнув ння (зміни гірських порід) вн слідок фізичної т хімічної дії різних тмосферних гентів т орг нізмів. ез вивітрюв ння не може відбутись жоден екзогенний процес. іншого боку, с мі процеси вивітрюв ння без уч сті інших рельєфотвірних процесів не створюють форм рельєфу, вони лише готують рельєф до тр нсформ ції. ивітрюв ння відбув ється шляхом мех нічної дезінтегр ції (фізичне вивітрюв ння) т розчинення порід і сполучення їх у нові хімічні зв'язки (хімічне вивітрюв ння). роцеси вивітрюв ння м ють величезне зн чення в рельєфотворенні. о геоморфологічних н слідків вивітрюв ння н леж ть руйнув ння т утворення гірських порід і мінер лів, формув ння грунтів, більш посилене переміщення мінер льних м с. дним з головних н слідків вивітрюв ння є утворення елювію.

роцеси вивітрюв ння прит м нні всьому р йону дослідження. Йяскр віше вони простежені н місцях з перемінним зволоженням (стічні, з лізничні водорегулюв льні споруди, скельні відслонення т ін.).

хилові процеси одні 3 н йбільш небезпечних, особливо в гірській місцевості. е винятком $\epsilon$ i досліджув н територія. н слідок близького 3 ляг ння до поверхні воротищенської соленосної товщі в околицях елятин ч сто відбув ються зсуви грунту [11]. елятині 1955 р. вн слідок обв лу схилу були з сип ні житлові будинки i дорог . отоки тягнули к міння ді метром 1,0-1,5 м, н 40-50 м бул перенесен з лізобетонн основ мост з вширшки 5-6 м [8]. присілку евелівк н пр вому березі р. олонець 1983 р. відбувся зсув грунту, що переріз в шосейну дорогу обл сного зн чення. 1982 р. зсувні процеси спостеріг ли у східній ч стині елятинської улоговини в долині р. сл в . сувними процес ми було пошкоджено лісові м сиви в урочищі іпч н площі пон д 1,5 г [7]. продовж 1976-2008 pp. зсуви щороку відбув лися н березі р. олонець. сувні тіл досяг ли площі до $1500 \mathrm{~m}^{2}$ т 3 г льного об'єму до 30 тис. ${ }^{3}$. ост нні 20 років долину ріки розширено зсув ми н 6080 м. [33].

1982 р. в урочищі осіч виник зсув з кр йової ділянки шостої н дз пл вної тер си. овжин стінки відриву - 30 м, висот - 2-4 м. зн чимо, що цей зсув щороку ктивізується, особливо в період зливових дощів. сувн м с н цей момент ст новить близько 2 тис. м ${ }^{3}$. енших розмірів зсуви відбув ються м йже повсюди, одн к н йбільше - н бровк х четвертої-шостої н дз пл вних тер с.

йбільший зсув з ост нні роки ст вся 2004 р. з бровки четвертої н дз пл вної теp си p. рут, н лівому березі р. юбіжня в місці їі перетину з лізницею в но- p нківськ- елятин (рис. 1). н слідок зливових дощів (пон д 120 мм 3 п’ять днів) сповзл величезн м с грунту. тінк відриву у формі серп м л довжину до 60 м, товщин знесеного ш ру - 10-18 м. б’єм зсувного тіл ст новив близько 10 тис. м $^{3}$. сувом пошкоджено житлові будівлі т спричинено зупинку з лізничних перевезень н лінії в но- р нківськ- елятин.

остійні зсувні процеси, осипи відбув ються в урочищі егельб (рис. 2), де н поверхню виходять воротищенські глини. сувні тіл м ють об'єм до 400-500 м³, осипи $50-100 \mathrm{~m}^{3}$.

сипи простежують н всіх ділянк х, що м ють крутість 40-50 і пройдені суцільними вирубк ми лісу. йяскр вішим прикл дом нег тивного впливу господ рської діяльності н розвиток гр віт ційних процесів є осипн ділянк, що утворил ся у середині 1970-х років ун слідок зсуву, яким було знесено ш р грунту до корінних порід. 
уйнув ння корінних порід (нижньоменілітов світ ) т розт шов них вище грунтових відкл дів відбув ється постійно. 25 років площ осипної ділянки у формі трикутник збільшил ся н $50 \%$, шорічний об'єм знесеного м тері лу ст новить від 20 до 50 м³ [33].

р ктично вертик льні стінки н обох берег х р. рут н сході досліджув ної території, поблизу с. обротів, утворені н перетині рікою північно-з хідного крил тектонічно ктивної обротівської скл дки, вони є пост ч льник ми осипного м тері лу в долину руту [11].

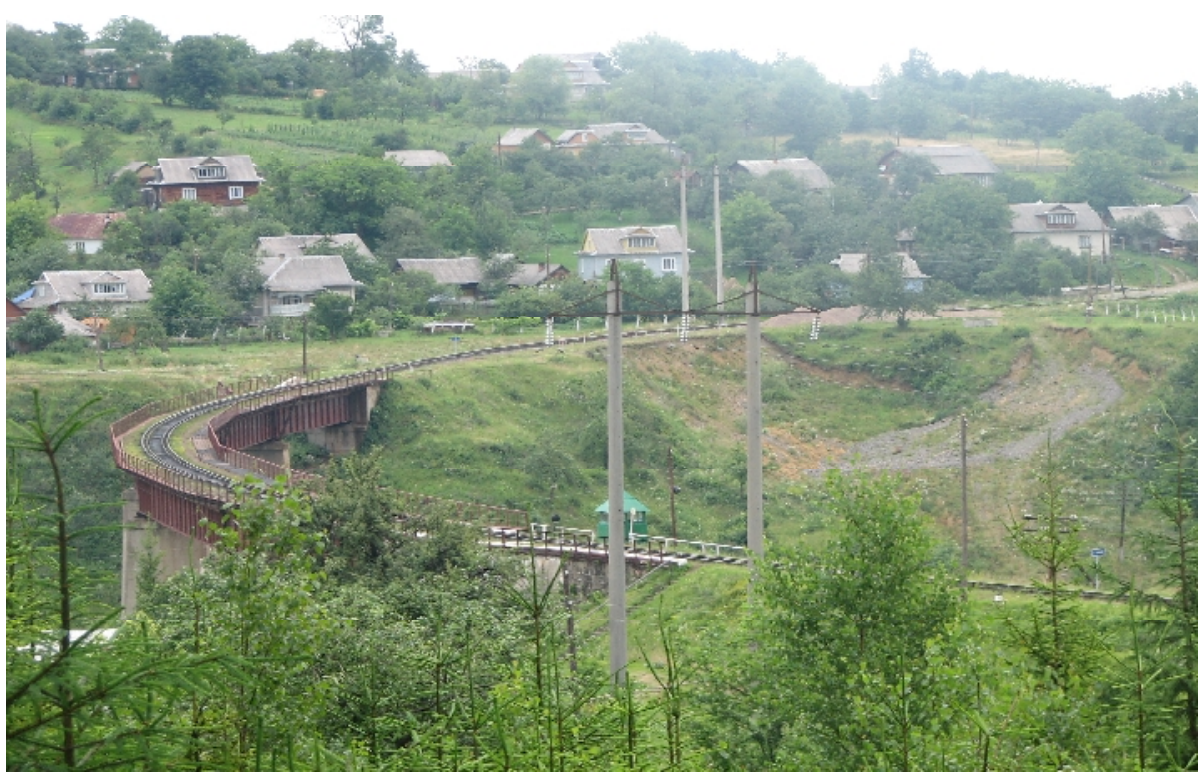

ис. 1. сув н лівому березі р. юбіжня.

ед леко від цієї місцевості розт шов ні ще дві ділянки з дуже крутими схил ми (урочищ огребнич т егельб ), які неоднор зово були причиною припинення руху з лізничного тр нспорту н з лізничній гілці оломия- елятин (рис. 3).

кі ж процеси відбув ються і в інших ч стин х елятинської улоговини - в к ньйоно-подібній долині р. еремиськ, що в присілку ориш, т н пр вому березі p. рут, у долині р. сл в поблизу їі гирл [33].

схил х досліджув ної території поширені т кож процеси м сового зміщення пл щ ул мків - повільне зміщення грунту відбув ється вн слідок пл стичних (в'язкопл стичних) деформ цій [25]. ричини цього типу руху н йч стіше пов'яз ні зі змін ми темпер тури, вологості. орми, утворені цим процесом, у елятинській улоговині м ють рівну з дернов ну поверхню і не м ють, н перший погляд, специфічних морфологічних особливостей. роте н деяких ділянк х м си рух ються вже не у вигляді пл щ, який повільно сповз $є$, у вигляді перерв ного зміщення окремих блоків поверхневого ш ру (міні тюрний зсувний процес). ей різновид дефлюкції прийнято н зив ти децер цією (рис. 4). ро неї свідч ть мікросходини н схилі. ип с ння худоби ктивізує процес, ун слідок чого утворюється рельєф коров'ячих стежок. кий процес поширений н 6 г тьох нез ліснених схил х крутістю пон д $20^{\circ}$. 
н чно поширені т кож делюві льні процеси, суть яких поляг є у змив нні ч стинок грунту дощовими і т лими вод ми. ей процес відбув ється пр ктично н всіх нез дернов них схил х. елюві льні процеси можн розділити н площинний змив і ерозію.

нтенсивність делюві льного процесу з лежить від: 1) кількості води, що стік є; 2) руйнівної дії кр плин дощу; 3) швидкості, з якою вод стік є; 4) вл стивостей грунту;

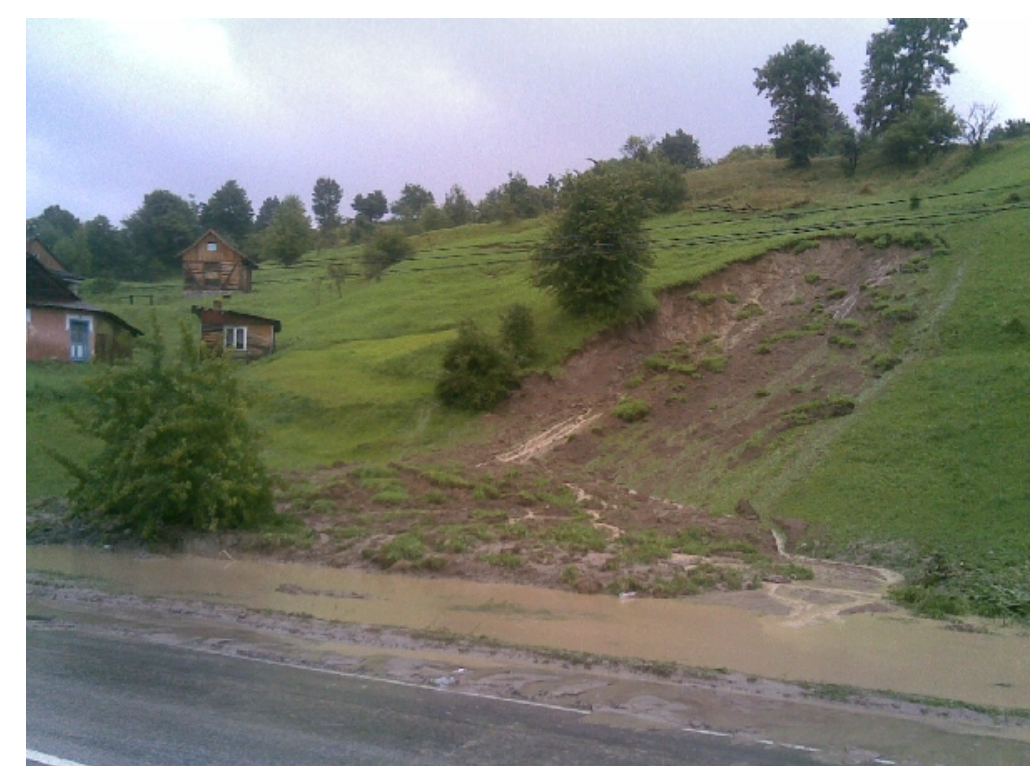

ис. 2. сувні процеси в урочищі егельб .

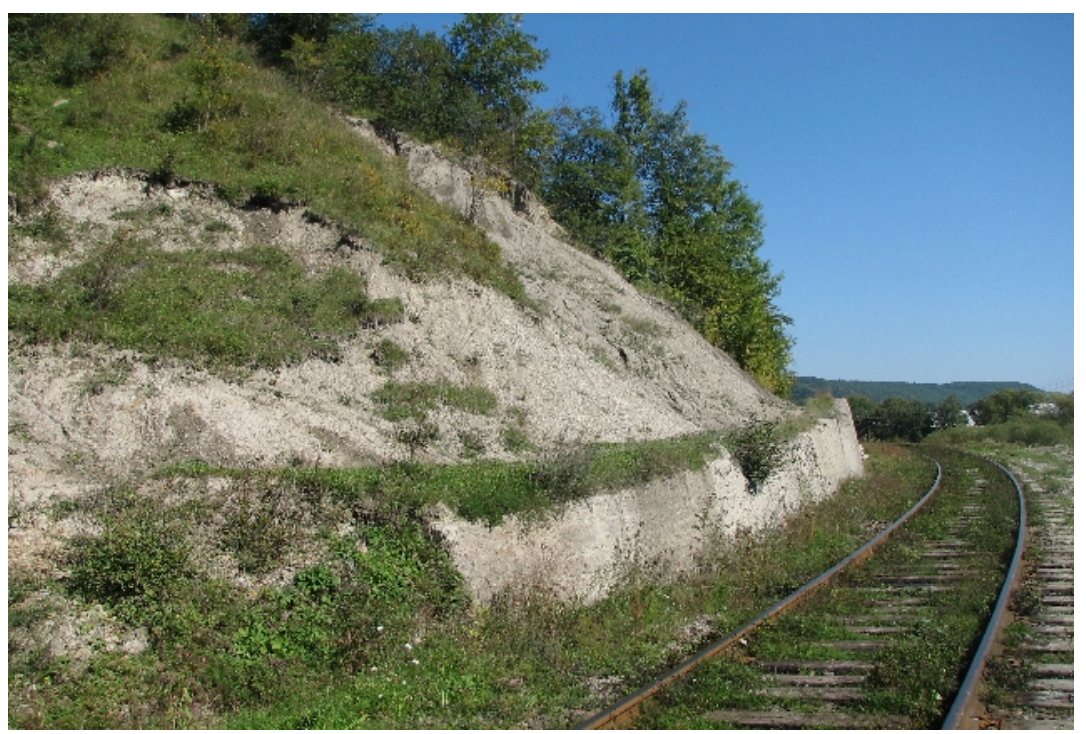

ис. 3. сувні процеси н лівому березі р. рут в урочищі егельб . 


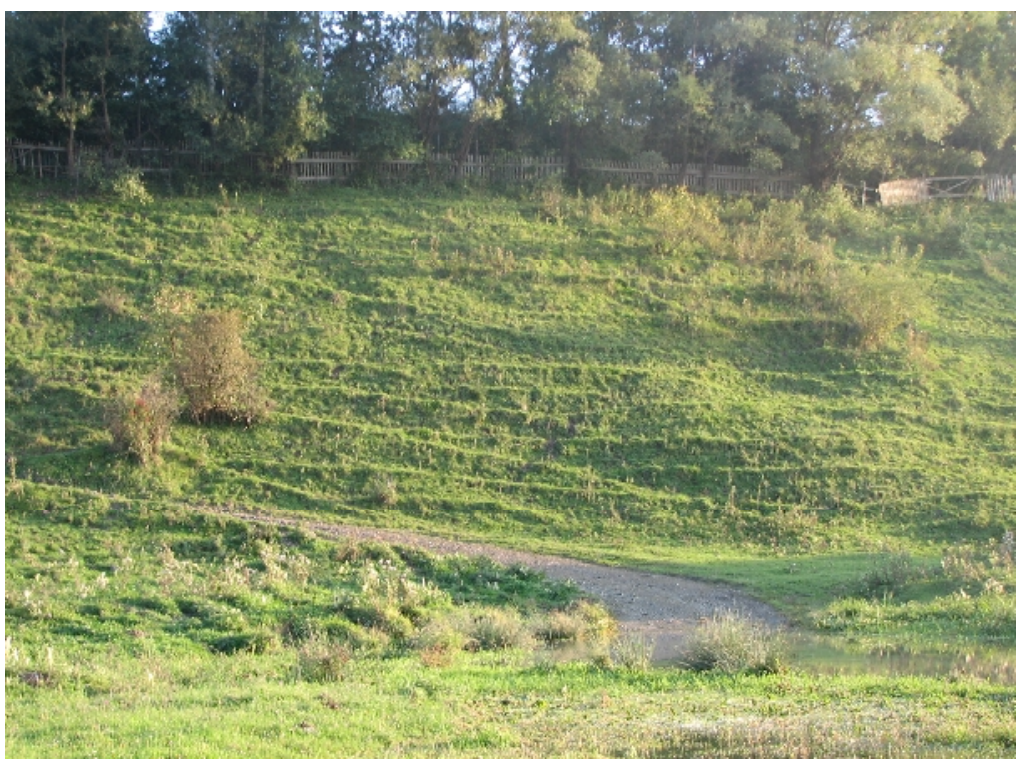

ис. 4. ецер ція н уступі третьої н дз пл вної тер си руту.

5) н явності і щільності рослинного покриву; 6) мікрорельєфу схилу; 7) крутості і довжини схилу; 8) експозиції схилу.

скільки схили р йону досліджень в основі скл дені перев жно глин ми воротищенської світи, то можн ск з ти, що цей процес н був тут двоякого розвитку: з одного боку, глин м $є$ низьку просочув ність, що сприяє розвитку процесу, 3 іншого, - глинисті ч стинки в процесі розмок ння ст ють своєрідним цементом для крупніших ч стинок н схилі, що сповільнює делюві льний процес [12]. ому глинисті грунти в природному ст ні н дзвич йно стійко опир ються розмив нню струмк ми. отужність делювію не є одн ковою по всій території. ля делюві льних відкл дів х р ктерн 30$50 \%$ пористість, висок к рбон тність, н явність горизонтів похов них грунтів. гром дження делювію відбув ється імпульс ми - після злив. ередня інтенсивність ос дон гром дження - десяті ч стки міліметр $з$ рік.

люві льні процеси - це сукупність геоморфологічних процесів, які відбув ються під впливом поверхневих водних потоків. елятинськ улоговин є регіоном з дост тнім і н дмірним тмосферним зволоженням. лизько $80 \%$ з г льної кількості оп дів прип д є н літній ч с, м ксимум їх спостеріг ють н вододільних ділянк х [8]. н чн кількість оп дів вип д $є$ у вигляді злив з сильними гроз ми, проте н йтиповішими $є$ мрячні дощі. рік у цій місцевості вип д є близько 700 мм оп дів. елик кількість тмосферних оп дів, їхній розподіл по місяцях і сезон х року зн чно вплив ють н розвиток т поширення ерозійних процесів. собливо повноводними і небезпечними ст ють під ч с літніх п водків м лі ріки, пр ві т ліві притоки р. рут. ід ч с п водк чи повені ріки переносять величезну кількість м тері лу, з вд ють величезних збитків і з бир ють життя людей. м вд лося простежити певну хронологію р птових підйомів рівня води з 1868 до 2007 рр. (т бл. 1, 2).

е одним не менш небезпечним явищем є селі - це грязьово-к м'яні, грязьово-щебеневі, грязьові потоки, які рух ються схилом, руслом гірського потоку, л винним лотком тощо і в яких вміст твердого м тері лу в дв -п’ять р зів перевищує вміст води [16]. 
оловними чинник ми формув ння твердого стоку селевих п водків з огляду н велику з лісненість схилів є н явність ул мкового м тері лу, н гром дженого н відткритих ділянк х схилу і в днищі долини, т кож діяльність людини - вирубув ння лісів, яке призводить до розвитку мережі ярів т б лок, винесення ул мкового м тері лу в низинні ділянки. н чний вплив н утворення селевих потоків м ють трелюв ння і вивезення деревини по русл х рік [21].

водки н р. рут у 1868-1982 pp. [30]

блиця 1

\begin{tabular}{|c|c|c|}
\hline $\mathbf{T}$ & $\begin{array}{l}\text { итр т води, } \\
\mathrm{M}^{3} / \mathrm{c}\end{array}$ & вд ні збитки \\
\hline 26.05 .1868 & & несено близько 3000 стовбурів з к шиць \\
\hline 1889 & & нищено мости т к шиці \\
\hline $\begin{array}{l}\text { р вень-червень } \\
1893\end{array}$ & & $\begin{array}{c}\text { ві повені знищили мости і дороги (припинено рух н } \\
\text { возовій дорозі) }\end{array}$ \\
\hline ервень 1899 & & $\begin{array}{c}\text { ідмито возову дорогу т з лізницю (н чотири дні } \\
\text { припинено рух поїздів) }\end{array}$ \\
\hline ерпень 1901 & & од несл худобу і господ рські споруди \\
\hline $\begin{array}{l}1912 \text { чи } 1913 \text { (3 } \\
\text { різними д ними) }\end{array}$ & & $\begin{array}{c}\text { в ж ли т ким, як у } 1969 \text { р., підвищення рівня води } \\
\text { н } 4 \text { м }\end{array}$ \\
\hline $10-14.07 .1927$ & & $\begin{array}{l}\text { од текл по центру елятин , знищено міст н } \\
\text { річчя, б г то житлових т господ рських споруд }\end{array}$ \\
\hline 07.1932 & & топлено господ рств селян \\
\hline 09.1933 & & \\
\hline 12.06.1948 & 1040 & 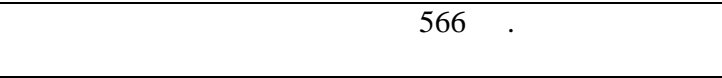 \\
\hline \multicolumn{3}{|l|}{8.07 .1950} \\
\hline \multicolumn{3}{|l|}{$30.07-10.08 .1955$} \\
\hline $17-21.07 .1957$ & & $\begin{array}{rlr}\text { ідвищення рівня води н } & 610 \mathrm{~cm} . & \text { топлено } \\
\text { господ рств } & \text { селян } & \\
\end{array}$ \\
\hline \multicolumn{3}{|l|}{15.06 .1959} \\
\hline $8-10.06 .1969$ & 1530 & $\begin{array}{c}\text { п ди 200-300 мм. ксим льне підвищення } 760 \text { см. } \\
\text { нищено більшість доріг т мостів, н декільк тижнів } \\
\text { припинено рух тр нспорту. битки ст новили } \\
10571 \text { тис. крб. }\end{array}$ \\
\hline $11-15.05 .1970$ & & битки ст новили 3 649,6 тис. крб. \\
\hline $25.05-4.06 .1970$ & & $\begin{array}{c}\text { ідвищення рівня води н } 3-5 \text { м. битки ст новили } \\
4694,3 \text { тис. крб. }\end{array}$ \\
\hline $29-30.06 .1974$ & & битки ст новили 1711,0 тис. крб. \\
\hline 21-22.07.1974 & & $\begin{array}{c}\text { битки ст новили } 4 \text { 461,0 тис. крб., змито дв житлові } \\
\text { будинки в центрі } \quad \text { елятин }\end{array}$ \\
\hline 29.07 .1980 & & еремито втодорогу уровичі- ук чеве у елятині \\
\hline
\end{tabular}

6 сейні гірського руту з період з 1900 по 1941 pр. селі з фіксов ні п'ять р зів, з 1948 по 1964 - сім, $з 1964$ по 1994 рр. -дев’ять р зів [32]. ке збільшення кількості селевих явищ зумовлене, очевидно, інтенсивним вирубув нням лісів у післявоєнні роки (рис. 5). елятинській улоговині всі ріки з числені до к тегорії селенебезпечних. собливо це стосується б сейнів річок еремиск т юбіжня. 
блиця 2

водки н рік х рут т онк в 1982-2007 pp. [30].

\begin{tabular}{|c|c|c|c|}
\hline $\mathbf{T}$ & итр т води, $\mathbf{m}^{3} / \mathbf{c}$ & вердий стік, г/м $\mathbf{m}^{3}$ & ік \\
\hline 10.07 .1982 & & & pyт \\
\hline 01.06 .1986 & & 4,200 & OHK \\
\hline 28.09 .1987 & & 3,100 & OHK \\
\hline 08.09 .1988 & & 90,000 & OHK \\
\hline 09.08 .1989 & & 13,000 & OHK \\
\hline 28.02 .1990 & & 1,400 & OHK \\
\hline 28.07 .1991 & & 2,500 & OHK \\
\hline 24.07 .1992 & & 2,200 & OHK \\
\hline 23.07 .1993 & & 3,400 & OHK \\
\hline 06.06 .1994 & & 5,900 & OHK \\
\hline 28.06 .1995 & & 14,000 & OHK \\
\hline 18.09 .1996 & & 30,000 & OHK \\
\hline 07.06 .1997 & & 8,900 & OHK \\
\hline 20.06 .1998 & & 4,600 & OHK \\
\hline 28.07 .1999 & & 5,100 & OHK \\
\hline 14.07 .2000 & & 59,000 & OHK \\
\hline 01.07 .2000 & 101 & & pyT \\
\hline 02.07 .2000 & 125 & & pyт \\
\hline 03.07 .2000 & 174 & & рут \\
\hline 04.07 .2000 & 192 & & pyт \\
\hline 05.07 .2000 & 218 & & pyт \\
\hline 06.07 .2000 & 231 & & рут \\
\hline 07.07 .2000 & 231 & & pyт \\
\hline 08.07 .2000 & 224 & & pyт \\
\hline 09.07 .2000 & 215 & & pyт \\
\hline 10.07 .2000 & 200 & & pyT \\
\hline 11.07 .2000 & 158 & & pyт \\
\hline 12.07 .2000 & 142 & & pyт \\
\hline 13.07 .2000 & 131 & & pyт \\
\hline 14.07 .2000 & 119 & & pyт \\
\hline 15.07 .2000 & 108 & & pyт \\
\hline 04.03 .2001 & 103 & 77 & pyт \\
\hline 05.03 .2001 & 202 & 360 & pyт \\
\hline 20.06 .2001 & 202 & 440 & pyт \\
\hline 21.06 .2001 & 187 & 240 & рут \\
\hline 22.06 .2001 & 122 & 20 & pyT \\
\hline 29.07 .2001 & 125 & 16 & pyT \\
\hline 16.08 .2002 & 231 & 95 & pyт \\
\hline 17.02 .2002 & 192 & 180 & pyт \\
\hline 14.07 .2003 & 269 & 480 & pyт \\
\hline 15.07 .2003 & 269 & 700 & pyт \\
\hline 31.07 .2003 & 233 & 330 & рут \\
\hline 01.08 .2004 & 188 & 180 & pyт \\
\hline 05.08 .2004 & 119 & 93 & pyт \\
\hline 06.08 .2004 & 102 & 37 & pyт \\
\hline 07.08 .2004 & 185 & 190 & pyт \\
\hline 09.06 .2005 & 177 & 410 & pyT \\
\hline 29.03 .2006 & 112 & 60 & pyт \\
\hline 02.06 .2006 & 224 & 380 & pyт \\
\hline 30.06 .2006 & 112 & 320 & pyт \\
\hline 12.09 .2007 & 1000 & 750 & pyт \\
\hline
\end{tabular}




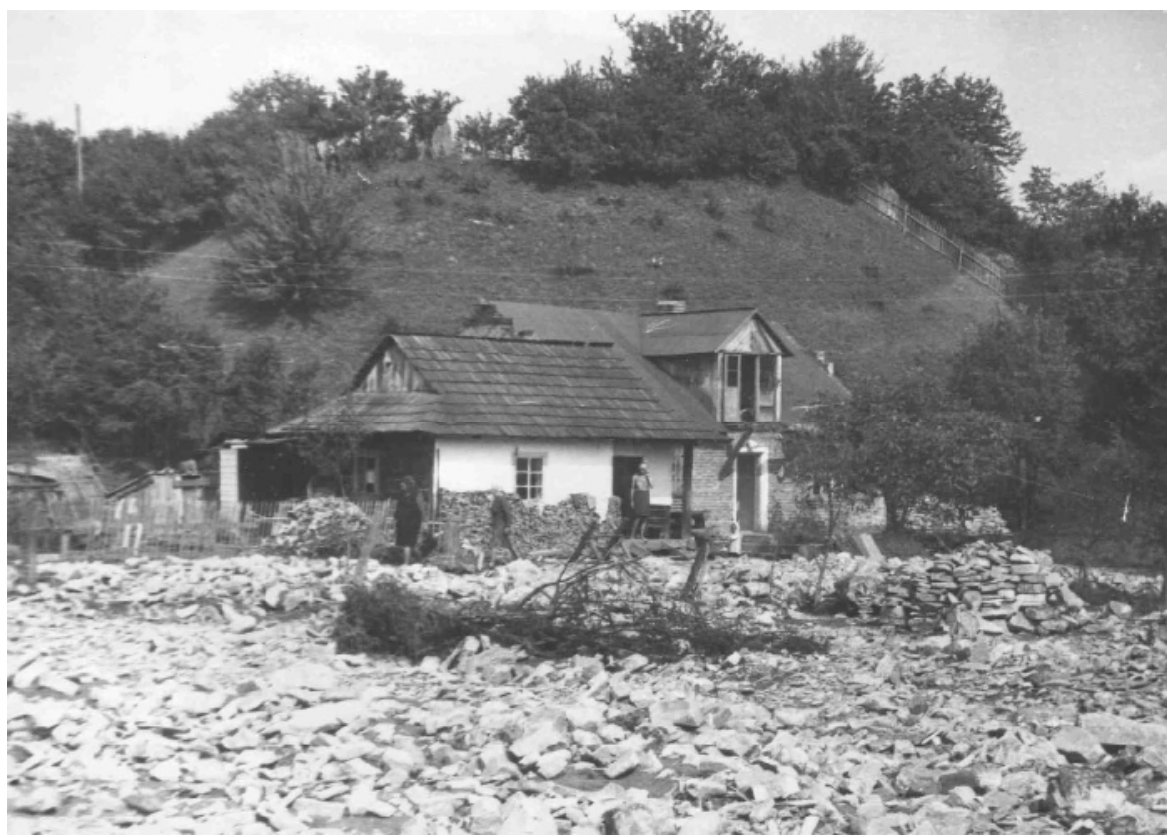

ис. 5. ель у присілку юбіжня 1955 р.

ксим льний к т строфічний п водок н р. рут з реєстров но 8-9 червня 1969 р., коли витр т води н ремч нському гідропості ст новил $1530 \mathrm{~m}^{3} / \mathrm{c}$ (середній 6 г торічний пок зник - 12,3 м³/с), середня швидкість течії - 4-5 м/с, м ксим льн висот хвиль - 2,5-5,0 м н д меженним рівнем. ік відкл л пон д 297 тис. м н носів, відкл ди, винесені її приток ми, виявляли н проміжку 30-35 км.

елеві п водки в б сейні приток руту спостеріг ють один р з в три-п'ять років. йпотужніші з фіксов ні в 1927, 1955 і 1969 рр.

пит нні, яке розгляд ємо, в жливим є прогнозув ння термінів проходження селевих п водків. н ш погляд, для цього необхідне: визн чення селенебезпечних релів у б сейн х рік; н ліз історичних д них щодо конкретного б сейну; розр хунок можливого розвитку інфр структури регіону; н явність гідротехнічних споруд у селенебезпечному 6 сейні; кількість ул мкового м тері лу в конкретному б сейні.

жливе зн чення для вивчення т попередження к т строфічних п водків м ють точні метеопрогнози н д леку перспективу, скл д ння яких, незв ж ючи н явне поліпшення прогнозів погоди ост нніми рок ми, є нині нере льним.

рстові процеси. квітні 2004 р. у елятині н висотній з пл ві р. олонець (лів приток p. юбіжня) утворилось пров лля ді метром 4 м т глибиною 14,5 м, що відp зу ж було з повнене водою зі зн чним вмістом солі [31]. еред утворенням пров лля вип ли сильні дощі, яким передув ли зн чні оп ди у вигляді снігу. чевидно, ктивізув лись процеси розмив ння соляних відкл дів, що м ють у р йоні елятин зн чні покл ди (від 100 до 1100 м). ійк з 2004-2008 рр. розширил сь до 10 м, іiї глибину з'ясув ти не вд лось. е явище соляного к рсту сильно розвинуте в р йоні елятин . прикл д, поверхня четвертої н дз пл вної тер си р. рут у присілку огребнич ускл днен різними к рстовими форм ми. поверхні цієї тер си тр пляється б г то 
лійок соляного к рсту з вглибшки 10-12 м і ді метром 10-50 м, іноді - до 200 м. но лійок здебільшого з болочене. они виникли в соленосних відкл д х воротищенської світи, які з ляг ють близько до поверхні під м лопотужним ш ром г лечників і суглинків. кремі ділянки прямокутної форми м ють зн чні розміри - 40×120 м, інші лійкоподібні. дні однієї з т ких лійок н поверхні води є острівець ді метром 4 м.

зн чимо, що к рстові процеси н цій ділянці менш поширені, ніж у середині ст., що зумовлене, очевидно, припиненням промислового видобув ння солі у довоєнний період.

роцеси з болочення в досліджув ній місцевості відбув ються т м, де виник ють умови для н дмірного зволоження грунту. ншим чинником, що зумовлює поширення боліт, є рельєф. йсприятливіші для утворення боліт рівнини т низовини, бо т кий рельєф зводить до мінімуму поверхневий стік води. решті, ще одним в жливим чинником утворення боліт є літологія гірських порід (глинисті породи з тримують просочув ння води). ур хув нням цих обст вин ст є зрозумілим, чому с ме н другій-третій н дз пл вних тер с х p. рут можн виявити незн чні 3 площею $\mathrm{i}$ глибиною болот [34].

тже, у елятинській улоговині зн чно поширені т кі суч сні екзогенні процеси, як вивітрюв ння, схилові, флюві льні, к рстові з болочення т ін. йбільшої шкоди господ рству з вд ють к т строфічні п водки, селі, зсуви т к рст. ожн т кож конст тув ти, що періодичність цих процесів з кожним десятиліттям збільшується і причиною цього є, н с мперед, нер ціон льне використ ння природних ресурсів і виробнич діяльність.

1. йзенберг . ., ундин . ., еменихин . . д стровые д нные селей в кр инских рп т х и их оценк // р. кр . 1983. ып. 194. . 116-121.

2. иблюк ., ов льчук ., тир нівський . кологічні проблеми уцульських рп т т шляхи їх вирішення // сторія уцульщини. ьвів: огос, 2001. . 6. . .540-570.

3. іл нюк ., омин . ктивіз ція геоморфологічних процесів у горг нських л ндш фт х, спровоков них функціонув нням м гістр льних трубопроводів // iсн. ьвів. ун-ту. ер. геогр. 2004. ип. 30. . 14-19.

4. олюх . ., н $и$., ., um . ., $p$ виук. . т цион рное изучение плоскостного смыв

в редк рп тье. ьвов: ищ школ , 1976. 113 с.

5. ожик . . еоморфологія долини р. руту // еоморфологія річкових долин кр їни. .: ук. думк , 1965. . .86-89.

6. ожик . . о пит ння геоморфології долини р. рут // оп. 1962. № 7. .942-945.

7. л пчук. . нтропогенний вплив н розвиток гр віт ційних процесів у долині верхнього руту // уч сні геогр фічні проблеми кр їнської .б. тез. доп. VI зїзду еогр. т-в ., $1990 . \quad$. 104-105

8. $л$ пчук . . т пи розвитку річкових долин б сейну верхнього руту: исерт ція...к нд. геогр. н ук. ., 1993.

9. л пиук. ., ымчук . ., ушняк . . елев я деятельность, к т строфические п водки рек б ссейн горного рут и возможности их прогноз // уч. сообщ. Х межвуз. коорд. совещ. по проблеме эроз., русл. и устьевых процессов. ологд , 1995. . 62-63.

10. $р$ вчук . еоморфологія кибових рп т. ьвів: ім. . p нк, 2005. 231 с.

11. $р$ виук . . еоморфологія ередк рп ття. ьвів: ерк тор, 1999. 188 с.

12. $p$ вчук . . лежність суч сних геоморфологічних процесів від типологічних особливостей рельєфу // існ. ьвів. ун-ту. ер. геогр. 1982. ип. 13. 
13. $p$ вчук . . ельефообр зующие процессы и их дин мик в кр инских рп т х и прилег ющих территориях // естн. ьвов. ун-т . ер. геогр. 1984. ып. 14. . 20-25.

14. врук ., ельник ., ов льчук. кологічні проблеми уцульщини // сторія уцульщини. ьвів: огос, 1999. . . . . 89-92.

15. ельник . . ндш фтно-екологічн оцінк нег тивних рельєфотвірних процесів в кp їнських рп т х // існ. ьвів. ун-ту. ер. геогр. 1999. ип. 26.

16. ельник . . ндш фтно-геогр фічні особливості поширення селевих і п водкових явищ в кр їнських рп т х // еоморфол. дослідження в кр їні: минуле, суч сне, м йбутнє: тері ли, міжн р. н ук. конф. ьвів, 2002.

17. лиферов . . елевые потоки в рыму и рп т х. имферополь, 2007.

18. удько .. еодин мік т прогноз небезпечних геологічних процесів в кр їнських рп т х // еодин мік гірських систем вропи: ези доп. іжн р. симпозіуму. ьвів, 1994.

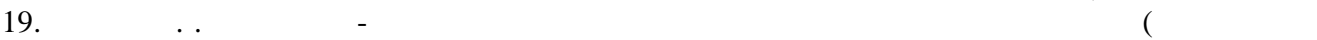
$55 \mathrm{c}$.

рп тського, римського т вк зького регіонів): втореф. дис. ... Д-р геогр. н ук. ., 1996.

20. ливк . . ро сельовий стік в кр їнських рп т х т методи його регулюв ння // існ. ьвів. ун-ту. ер. геогр. 1994. ип. 19.

21. ливк . ., олояд . ., невник . . розійно-денуд ційні процеси в кр їнських рп т х. в но- р нківськ, 1995. 114 с.

22. $m$ дницкий . ., pвчук. , олюх . . звитие эрозионных процессов в кр инских рп т х // еоморфология. 1975. № 1.

23. $m$ дницький . ., $\quad$ в вчук . . еолого-геогр фічні передумови розвитку і поширення суч сних стихійних процесів в кр їнських рп т х // еогр. проблеми кр їнських рп т оділля: ІІ з'їзд еогр. т-в . . ., 1970.

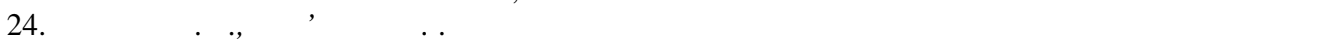
в кр їнських рп т х // ук. пр. кр .1999. ип. $247 . \quad$. 114-124.

25. омин . . езульт ти ст ціон рного дослідження дефлюкційних процесів н південно-з хідних схил х кр їнських рп т// роблеми геоморфології і п леогеогр фії кр їнських рп т і прилеглих територій: б. н ук. пр ць. ьвів:

26. ушняк , в ник . оль процесів гр віт ційної тектоніки у суч сному рельєфотворенні рп т // роблеми геоморфології і п леогеогр фії кр їнських рп т і прилеглих територій: б. н ук. пр ць. ьвів: ім. . р нк , 2006. . 182-186.

27. ушняк . собливості просторово-ч сової диференці ції суч сних екзогенних геоморфологічних процесів в кр їнських рп т х // існ. ьвів. ун-ту. ер. геогр. 2006. ип. $33 . \quad$. $454-457$.

28. ушняк . . лияние морфоструктурних особенностей кр инских рп т н р звитие оползневых процессов // кзогенний морфогенез в р зличных тип х природной среды. ., 1990.

29. блонский . . вязь м сшт бности селей рп т с природными и нтропогенными ф ктор ми селеформиров ния // р. кр . 1991. ып. 240. .97-122.

30. ом шній рхів л пчуків (н д лі- ). . 1. п. 3. пр. 4.

31. . . 1. п. 3. пр. 5 .

32. . . 1. п. 7. пр. 4.

33. . 1. п. 7. пр. 9.

34. ентр льний держ вний історичний рхів у ьвові. $.169 . \quad$ п. 1. пр. 41. рк. 1. 


\section{MODERN MORPHODYNAMIC PROCESSES IN DELYATYN CAVITY}

\section{Klapchuk}

Ivan Franko National University of Lviv, . Doroshenko St., 41, UA - 79000 Lviv, Ukraine

In the article the detailed description of processes in Delyatyn cavity is given (karst processes, slope processes, mud flow processes, bog processes and weathering processes). Most floods on the river Prut are resulted during 1868-2007. There is traced dynamics of slip processes during 1955-2007

Key words: modern morphodynamic processes, landslip, landfall, mud flow.

\section{- Л Пчук}

ьвовский н цион льный университет имени в н р нко, ул. . орошенко, 41, г. ьвов, 79000, кр ин

риведено дет льную х р ктеристику экзогенных морфодин мических процессов в елятинской вп дине (к рстовые, склоновые, селевые, болотные процессы и процессы выветрив ния), т кже информ цию о к т строфических п водк х н реке рут в 1868-2007 гг. и дин мике процессов сдвигов в 1955-2007 гг.

лючевые слов : современные морфодин мические процессы, сдвиг, обв л, сель.

т ття н дійшл до редколегії 09.06.2009 рийнят до друку 20.09.2009 